\title{
Evolution of Constitutional Norms in Post-Soviet States: Democratic Procedure or Approval of Quo Status?
}

\author{
Svitlana Bulbeniuk ${ }^{*}$ [0000-0001-9760-7850], Vira Haponenko 2 [0000-0002-1004-3165], \\ Yurii Maneliuk 2 [0000-0002-8186-7604] \\ ${ }^{1}$ Borys Grinchenko Kyiv University, Ukraine \\ ${ }^{2}$ Vadym Hetman Kyiv National Economic University, Ukraine \\ *s.bulbeniuk@kubg.edu.ua
}

\begin{abstract}
The paper focuses on the political and value-ideological aspects of the evolution of constitutional norms in the post-Soviet space and in Ukraine, in particular, which determine such specific features of the constitutional process as approval of changes by trial and error, "compromise", mobilization of public support for constitutional changes. the aspirations of the elite to monopolize or change power, cyclical repetition of constitutional reforms' content. A comparative analysis of changes to the constitution in Ukraine and other post-Soviet states according to the criteria of conservative constitutional process, reasons and drivers of changes to the Basic Law, the constitutional amendments' content, features of constitutional control institutions, features of the change process, their political consequences, which allows identify general trends and specific regime and socio-cultural features, formulate recommendations for optimizing the constitutional process. The main arguments of the author's position of the research team on the expediency and objectivity of constitutional changes in Ukraine in the democratization of the political system, criteria for assessing their content, general recommendations for political aspects of stabilizing and optimizing the constitutionalism of post-Soviet states.
\end{abstract}

Keywords: constitutional process, institutionalization, changes to the constitution, conservatism of the norms of the constitution, democratization of the political system.

\section{INTRODUCTION}

At the end of June 2021, the next anniversary of the adoption of the Ukrainian Constitution passed, which became the push for actualization of scientific discussions and public discussions on the feasibility and content of further constitutional changes and reforms. The outlined issues are interdisciplinary in nature, covering the heuristicconceptual field of political science, socio-psychological and legal sciences and areas of research. One of the little studied, in our opinion, is the political and social aspect, which has an axiological and normative nature and is designed to reveal socio-political and value-ideological factors shaping the content of the constitution, to identify the main contradictions of the institutional design of constitutionalism.

Despite long theoretical development, the question of the peculiarities of post-Soviet constitutionalism is inexhaustible given the latest realities of its functioning. At the same time, we consider it expedient to apply the neoinstitutional approach to the interpretation of the constitution as a set of social rules and norms that are inextricably linked with the behavior of political actors, as it allows a deeper understanding of subjective and objective interaction in the constitutional process.

Therefore, the aim of the study is to analyze changes to the constitutions of post-Soviet states as an institutionalization of democratic reforms, on the one hand, and as a mechanism of competition of political elites, on the other.

The methodology of our research is based on a comprehensive analysis of changes to the Constitution of Ukraine in the years of independence, which traces the optimization of institutional design, as well as a comparative review of the content and conditions of 
changes to the constitutions of Ukraine and other postSoviet states reasons and driving forces (initiator) of changes to the Basic Law, features of the process of changes' adoption, their political consequences. Given the research objectives, the authors applied elements of behavioral and psycholinguistic approaches to the analysis of the evolution of the constitutional process. Thus, the methodology of the presented intelligence is based on the principle of application of interdisciplinary pluralism.

\section{RESEARCH ANALYSIS}

\section{General features of post-Soviet constitutionalism}

The research used the conclusions of foreign and domestic theorists on the features of post-Soviet constitutionalism. Their essence is reduced to the following provisions. First of all, it should be noted the projective (teleological) nature of the constitutional process $[1,126]$. In the conditions of breaking the old institutional system and values, normative documents cannot consolidate real socio-political relations, so they are a kind of declarations. Such constitutional norms have a rather low level of public support, they are designed to perform an important social function of establishing a single national idea. This distinguishes the post-Soviet space from the Central and Eastern Europe countries, where at the time of the overthrow of the socialist regimes there was a relative consensus on the main directions of social development.

The constitutional process is doomed to take the form of trial and error, as it cannot approve the relations formed in the previous period. Such "wandering by deceivers" often demonstrates recurring phenomena, and the constitutional process involves certain cycles. Indicative in this case is the experience of Ukraine, whose constitution has undergone several "reversals" - the restoration of the old version of the Basic Law, and then return to the previous one.

According to the authors, the constitutional "reversals" in Ukraine are associated with difficulties in forming the mechanisms of sovereignty both in the period preceding the restoration of state independence and had imperial roots, and in the days of national statehood. Ukrainian sovereignty emerged as a political movement without a clear ideology and a response to crisis situations of legitimacy and legitimacy of political decisions within the state. Ukrainian sovereignty functions as a system of power relations based on binary positions, which serve as a means of constructing political reality $[2,44]$.

Thus, the Constitution of Ukraine has been amended 8 times in 25 years. At the same time, each edition was criticized. However, in our opinion, there is a tendency to improve the elements of institutional design, even in the process of spontaneous evolution.

Therefore, there is reason to believe that the positive dynamics of Ukrainian constitutionalism, as well as a certain degree of self-regulation of political system, that even in the struggle of major political actors for influence, it does not lose its synergistic properties striving for stability and balance.

This indicates the need to implement with caution changes at the constitutional level, preventing the imbalance of the system and promoting the "habituation" of general population to the current constitutional regime, increasing its legitimacy. We consider this conclusion fair for all post-Soviet states, which are called to carry out constitutional reforms from the standpoint of gradualism, preventing voluntary rewriting of normative documents, creating conditions for legitimation and approval of legal norms at the level of consciousness of all political actors and political practice.

The constitutions of the post-Soviet states are characterized by excessive detail, formalization of its norms. In contrast to classical democracies, in particular the countries of Anglo-Saxon law, young democracies tend to regulate in detail various aspects of political life. This entails the need to constantly change the constitutional norms, to harmonize with other normative documents.

This phenomenon can be analyzed based on the tools of modern psycholinguistics methodology. After all, sociopolitical vocabulary plays a special role in crisis, transitional periods of state life, and its tools are designed to mark the socio-political reality, forming a discursivecommunicative field of society [3, 84]. So that, the excessive detail of the constitutions of the post-Soviet states was intended, although veiled, to promote the formation of a qualitatively different thesaurus of sociopolitical dialogue.

However, such a dialogue rather served as a formal cover for the imitation game of democracy. This fact can rightly be considered the legacy of the USSR. For example, the USSR constitution of 1978 affirmed all fundamental human rights, and its norms had a completely democratic meaning. However, the use of these rules was not possible in practice. For example, this document guaranteed every union republic the right to withdraw freely from the Soviet Union $[4,72]$.

\section{DISCUSSION OF RESULTS}

A comparative study of the content and circumstances of changes to the Basic Law of the post-Soviet states made it possible to identify both recurring and unique cases of the constitutional process, to formulate a number of patterns. 
The authors substantiate them according to separate criteria.

\subsection{Norms of conservatism of the constitutional process}

All states contain constitutional norms aimed at preventing frequent and unjustified changes. In particular, it is traditional to restrict the subjects of legislative initiative, complicate the procedure of transformation of certain articles or restrict subsequent changes to the constitution after its adoption.

The norms of constitutional "conservatism" in Ukraine are quite traditional. The decision to amend most sections of the constitution includes two stages: the preliminary approval of the parliamentary majority and the vote on the draft at the next regular session by at least two-thirds of the votes in the constitutional composition of parliament. It is significant that one convocation of the Ukrainian parliament under Art. 156 has no right to change more than once the same provisions of the Constitution of Ukraine [5].

However, this does not affect the practical indicators of the dynamics of change. There is a tendency of the largest number of changes to the Constitution in countries without fundamental democratic values. In particular, in the postSoviet states the basic law changed more often than in Central and Eastern Europe.

\subsection{The content of constitutional changes}

Most often, the content of the reform affects the distribution of powers of higher state authorities. The changes to the constitutions of Belarus are eloquent in this sense. Thus, in 1996, the constitution of this state, updated in a referendum, strengthened the role of the executive power and the president, and in 2004, the restriction on one person to be elected president for more than two consecutive terms was lifted.

Similar is the practice of the Russian Federation, whose constitution in 2008 extended the term of office of the President and the State Duma, and in 2020 increased the term of office of the President to the detriment of the government. The main consequence of the latest large-scale revision of the basic law was the "zeroing" of the terms' amount for persons who have already held the post of president, including the current head of state.

In Ukraine, amendments to the Constitution are not explicitly authoritarian, but are often are the result of different political forces fighting for power. This gives grounds to believe that substantive changes to the constitutions in the post-Soviet states are not always objective, but only used as a mechanism for gaining and retaining (monopolizing) power, satisfying the ambitions of political elites.

\subsection{Causes and driving forces (initiator) of change}

Quite often (but not always!) changes to the constitutions of post-Soviet states were adopted under public pressure. Thus, the collapse of the USSR and the creation of independent states on its territory was a consequence of the "velvet revolutions". In Georgia, the Rose Revolution contributed to the deepest changes in the political system, with protests preceding a change in the electoral system in 2020 .

Actions of civil disobedience in Ukraine were an indispensable attribute of constitutional changes. The impetus for the amendments to the Constitution of the USSR was the protests in 1990, which in journalism were called "Revolutions on Granite" [6]. Despite the fact that the reforms took place under public pressure during actions of civil disobedience, they were led by the old partynomenklatura elite, whose main goal was to preserve their prerogatives and power. Therefore, the authorities satisfied only the basic slogans of the protesters, made partial concessions in order to reassure the public, rather than change the foundations of socio-political life. That is why the issue of adopting the constitution of independent Ukraine has been delayed for years.

Such a pattern can be seen at all stages of the constitutional process: mass actions of civil disobedience ended in a conditional "victory of the people", intensified discussions about the need for constitutional change, but did not promote national consensus, did not exclude social and political contradictions that caused a revolutionary explosion.

Undoubtedly, the activists of the protests in 2004 and 2013 resisted the authoritarian tendencies of the government, defended democratic values, and public organizations took the initiative to ensure security and law and order in the country in a power vacuum [6]. However, they affirmed the practice of "revolutionary expediency" of change and populist decision-making. Constitutional changes took place in violation of the procedure for their introduction, gave rise to such novelties of world constitutionalism as the "third" round of elections of the President of Ukraine.

These events were aimed at the rapid stabilization of the socio-political situation. Nevertheless, the country continued to be weakened by institutional and elite conflict, lack of consensus, and ineffective governance. This led to a wave of public frustration, growing discontent. In this way, the contradictions of Ukrainian constitutionalism 
were only preserved in anticipation of another aggravation of the situation.

Analysis of the causes and driving forces of these changes suggests that there is a clear correlation between constitutional "flexibility" and the level of "fragility" of the state functioning principles. Especially if we mention such components of the Index of Weak States [7] as: security apparatus, factional elites, economic decline, flight and brain drain, legitimacy of the state, public services, human rights and the rule of law, demographic pressure $[8,53]$.

In general, we consider the situation of public manipulation and, ultimately, the content of the constitution a consequence of the immaturity of civil society, the low level of political culture of post-Soviet citizens. Thus, the problem of institutionalized public participation in proposing and discussing changes to the constitution, avoiding or at least minimizing the influence of political expediency, populism on the content of the Basic Law is urgent.

\subsection{Features of the change approval process}

Concisely, the specifics of the political procedure for adopting changes to the constitutions of post-Soviet states can be described as demonstrative public involvement, prolonged confrontation between different political forces, non-compliance with formal procedures.

Such confrontation in the post-Soviet space is objective in nature, due to the conflict of old and new values, the unwillingness of the majority of elite and public to rapid radical change. At the same time, social political and ideological contradictions often turn out to be far-fetched. The debate over individual constitutional norms culminates in a compromise between political elites who, due to their inability to satisfy their interests at the current stage, seek to provide opportunities for maneuver in the future. This provokes constitutional instability, but indicates a lack of monopoly of one person or political force to control the constitutional process.

In such circumstances, the institution of control over the validity and legality of constitutional amendments is a political tool. A number of researchers recognize the formal role of the Constitutional Court in overseeing constitutional amendments in Azerbaijan, Kyrgyzstan, Moldova, and Ukraine. Often this institution can interfere in the constitutional process under certain conditions, such as on behalf of the head of state [9, 7-15].

\subsection{Political and social consequences of changes to the constitution}

Obviously, it is possible to give different assessments of specific constitutional reforms, but under any circumstances their content must meet such criteria as:

- objective necessity, expediency, maturity of changes, as opposed to amendments imposed by specific individuals or groups;

- ability of constitutional norms to form an idea of the main political goals and values, their compliance with traditional social ideas, national characteristics, the specifics of political culture. Historical circumstances of state formation, belonging to a certain civilization space;

- compliance of all elements of institutional system, consistency of amendments to the constitution with other legislative acts;

- flexibility of the constitution, which does not detail the details of institutional design, and therefore allows it to evolve naturally without willpower and power decisions under the influence of external conditions [10, 62];

- constitutional rules are designed to define the powers of the subjects of operational rules and rules of collective choice, which change much easier than the constitution $[11,217]$.

- a long process of drafting the constitution, aimed at identifying the views of all social groups, experts, stakeholders, removing controversial, potentially conflicting issues from the agenda and reaching consensus on all constitutional norms;

- a long period of functioning of the constitutional norms of the new edition;

- overcoming the binary of oppositions (worldview, political, legal, economic -this criterion is proposed by the authors), linearity of thinking, uncritical extrapolations of world and regional trends of political, economic, social development as general and universal trends, "Middleincome traps", say, as a single trend [12, 42].

\section{CONCLUSIONS}

An amount of features of the constitutional process of the post-Soviet states are due to objective factors. In particular, the projective nature of constitutions is due to the lack of consolidating political values, established traditions and experience of political relations in a democracy. We explain formalism by a weak political and legal culture, the weakness of the constitutionalism principles and attempts to replace real transformational changes with imitation models. 
Comparative analysis of the practice of amending the constitution in post-Soviet states

First, the number of amendments to the constitution does not depend on the legal procedure for amending it. In most states, it is standardized to ensure the "conservatism" of the constitutional process. But they are grossly neglected under the influence of political expediency in a low political and legal culture and the absence of traditions of democratic rotation of power.

Secondly, the adoption of new Constitutions does not mean progress, democratization, as they substantively affect the formal aspects, and in some cases reflect the political ambitions of individuals, remaining detached from political consciousness and practice.

Third, the norms of constitutional conservatism and the bodies of constitutional control are ineffective in the conditions of low involvement of civil society institutions in the process of drafting and adopting amendments to the constitutions.

Thus, the constitutional process in the post-Soviet states, in addition to detailing, clarifying the basic norms,

\section{REFERENCES}

[1] Proyss, Ul'rikh (1996), "Modely konstytutsyonnoho razvytyya y peremenu v Vostochnoy Evrope", Polys, no. 4 , pp. $125-136$.

[2] Zaporozhchenko, Ruslan (2021), "Sovereigntizm as a vocation and profession: imperial roots, current state, possible prospects", Ideology and Politics Journal, no. 1 (17), pp. 44-72, available at: https://www.ideopol.org/ (Accessed 27 October 2020)

[3] Kotsur, Vitalii Vilchynska, Iryna and Kotsur, Lesya (2020), "Actualizatsiia suspilno-politychnoi leksyky v pobutovomu dyskursi sub'iektiv komunikatsii”, Psycholinguistics, vol. 28 (2), pp. 82-98.

[4] Konstytutsiya Ukrayiny vid 20 kvitnya 1978 roku, available https://zakon.rada.gov.ua/laws/show/888-09\#Text (Accessed 27 September 2021)

[5] Konstytutsiya Ukrayiny, available at: https://www.president.gov.ua/documents/constitutio n (Accessed 11 October 2021)

[6] Revolyutsiya na hraniti 1990 roku: yakym buv pershyy ukrayins'kyy Maydan, available at: https://24tv.ua/revolyutsiya_na_graniti_1990_prichi ni_naslidki_uchasniki_foto_n1213193 (Accessed 17 October 2021) provides for a number of measures in the political and socio-cultural spheres. In particular, its optimization requires the integration of society, the promotion of the national idea and fundamental political values, going beyond a temporary compromise, finding a balance between unjustified delays in reforms and the artificial ephemerality of the adopted norms.

According to the analyzed criteria, Ukrainian constitutionalism fully fits into the post-Soviet trends. However, we also note the positive side of the constant rivalry between the interests of Ukrainian constitutionalism, which has prevented the introduction of an authoritarian scenario and the usurpation of power. This gives reason to hope for further transformation of the national political system in the direction of democracy.

In view of this, promising areas for optimizing postSoviet constitutionalism are the formation of a consolidated system of national values, ensuring the objectivity of changes to the constitution, and involving the public in the constitutional process in an institutionalized form.

[7] Minakov, Mykhaylo (2019), "Postup demokratiyi v Ukrayini (1991-2019), available at: http://sgsofia.com.ua/postup-demokratii-v-ukraini-19912019 (Accessed 12 October 2021)

[8] Pastarmadzhieva, Daniela (2021), "Electoral systems and functioning of the states", Journal of International Studies, vol. 14(3), 43-58, available at: https://www.jois.eu/files/3_1064_Pastarmadzhieva.p df (Accessed 27 October 2020)

[9] Berchenko, Hryhoriy (2020), “Konstytutsiynyy kontrol' za vnesennyam zmin do konstytutsiyi: zarubizhnyy dosvid", Publichne pravo, vol. 3 (39), pp. 9-16.

[10] Horowitz, Donald (1994), "Democracy in divided societies" / Diamond L., Planner M. Nationalism, ethnic conflict, and democracy, Johns Hopkins University Press, Baltimore, MD, pp. 61-112.

[11] Ostrom, Elinor (1992), "Crafting institutions for selfgoverning irrigation systems", ICS press, Oakland, CA, $220 \mathrm{p}$.

[12] Palekhova, Viktotiya (2021), "Why does Ukrainian economy grow so slowly?", Economics and Sociology, vol. 14(1), pp. 28-45. 